sometime in the 90 's when a party from the revenue cutter Corwin landed and shot 16.

The old trails Elliott mentions are still plainly seen, worn deep into the tundra. Skulls of several animals were found, all with bullet holes in them, and two were preserved. Very probably a few bears may still come down in winter on the ice pack but they have been hunted so much of late years that they cannot be common.

Microtus abbreviatus. Hall Island Meadow Mouse.-Runways of rodents completely undermine certain large areas of both St. Matthew and Hall Islands, but at the present time most of them are unused. Indeed "fresh signs" of mice were rarely found and the result of my trapping is a single adult female, skin and skeleton. The remains of others were collected in owl pellets and there appears to be more than one species. This material has not been critically examined, but in all probability it includes bones of Microtus a. fisheri Merriam, described from specimens taken on St. Matthew Island in 1899 by Dr. A. K. Fisher, during the visit of the Harriman Expedition.

\title{
NESTS OF THE WESTERN FOX SQUIRREL
}

\author{
By H. L. STODdARD
}

\section{[Plate 7]}

All accounts of the habits of the western fox squirrel (Sciurus niger rufiventer) that I have been able to find, speak of the young as being brought forth in hollow trees, no mention being made of the carefully constructed open nest used for this purpose in parts of the range of this squirrel.

In the sand dunes of northwestern Indiana particularly, where fox squirrels are still fairly abundant, the young born in early spring at least are usually brought forth in a very ingenious type of open nest, though hollow trees are common. These nests are round or oval in shape, tightly woven of freshly cut oak or other tough twigs. Inside of this twig shell comes a thick compact wall of large leaves, evidently pressed into shape while damp, making a smooth, tough lining capable of resisting wind, cold and rain. The nest proper is then made of soft inner bark, shredded leaves and other material.

The entrance hole is on one end and is just large enough to admit the owner, the surrounding fiber often nearly closing the opening. The accompanying figure, which is from a group prepared for circulation in the Chicago schools by the N. W. Harris Public School Extension of Field Museum, shows a typical nest in the original crotch, with one side removed to show details of construction. 


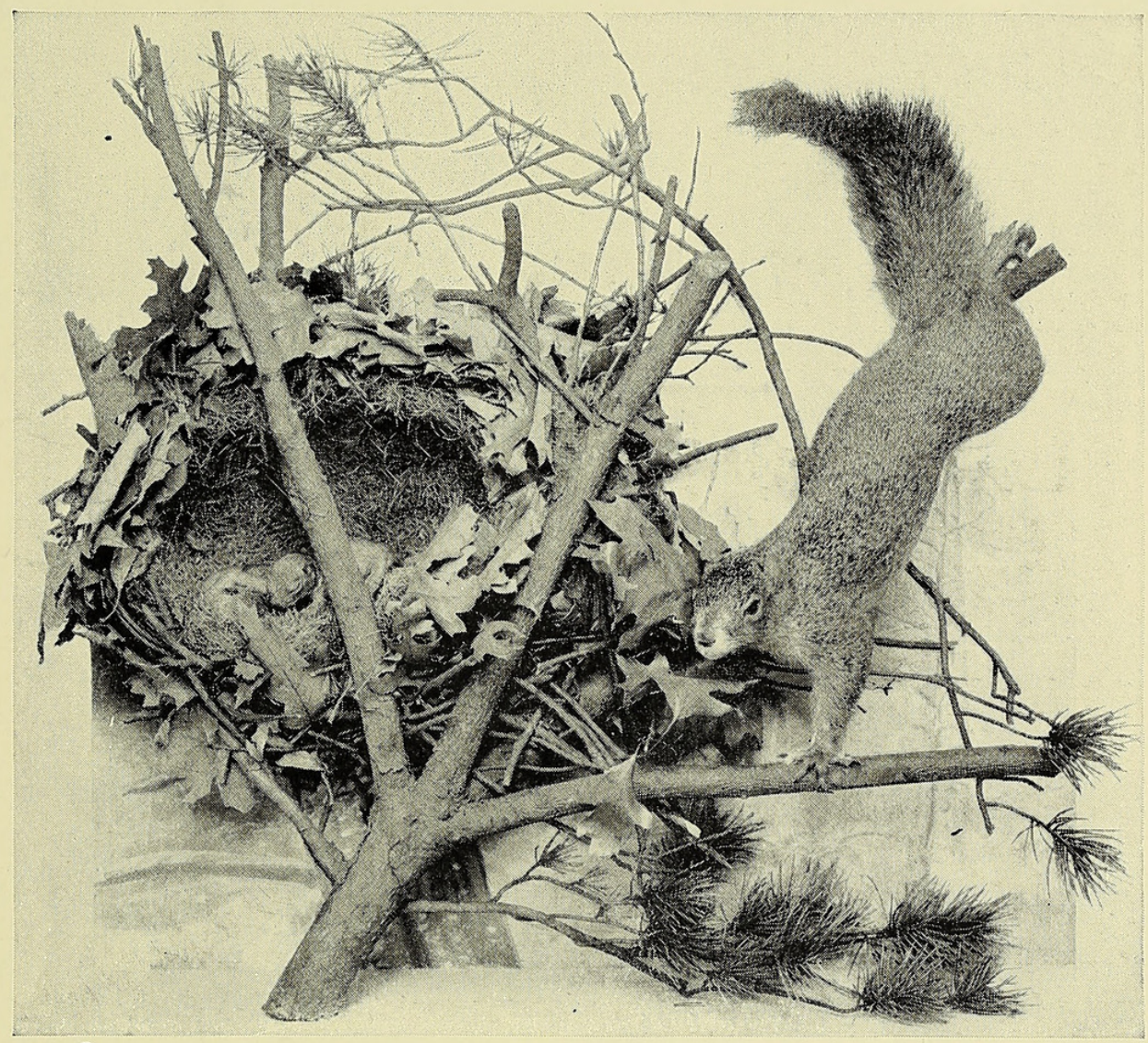

Nest of the Western Fox Squirrel

(Courtesy of the N. W. Harris Public School Extension of Field Museum) 


\section{$2 \mathrm{BHL}$ Biodiversity Heritage Library}

Stoddard, H L. 1920. "Nests of the Western Fox Squirrel." Journal of mammalogy 1, 122-123. https://doi.org/10.2307/1373335.

View This Item Online: https://www.biodiversitylibrary.org/item/220052

DOI: https://doi.org/10.2307/1373335

Permalink: https://www.biodiversitylibrary.org/partpdf/90499

\section{Holding Institution}

Smithsonian Libraries

\section{Sponsored by}

Biodiversity Heritage Library

\section{Copyright \& Reuse}

Copyright Status: Not in copyright. The BHL knows of no copyright restrictions on this item.

This document was created from content at the Biodiversity Heritage Library, the world's largest open access digital library for biodiversity literature and archives. Visit BHL at https://www.biodiversitylibrary.org. 